\title{
INCREASING EFL STUDENTS' DESCRIPTIVE WRITING SKILL BY USING VIRTUAL TECHNOLOGY ON ENGLISH LEARNING
}

\author{
By \\ Umar \\ Universitas Teknologi Sumbawa, NTB, Indonesia \\ Email: umar@uts.ac.id
}

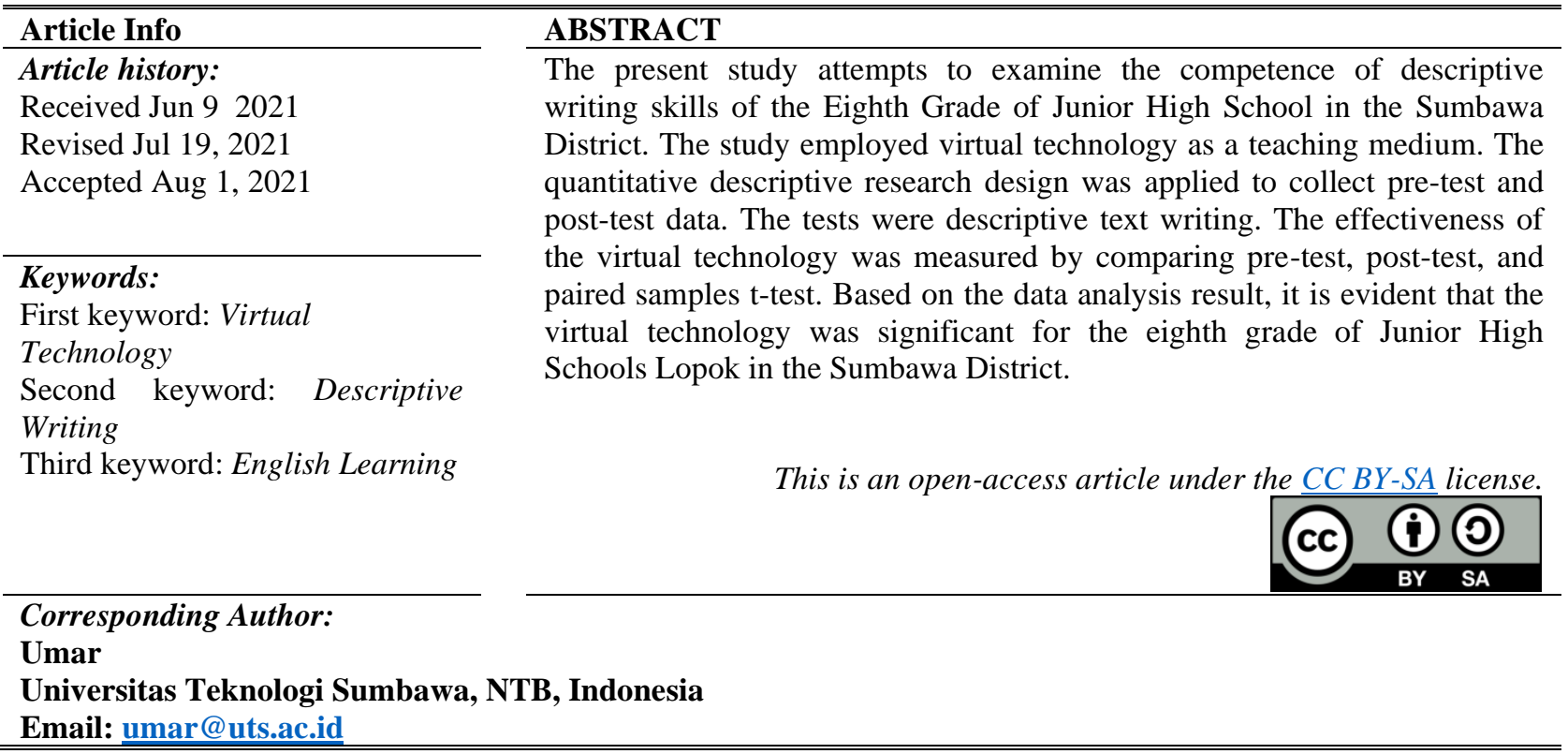

\section{INTRODUCTION}

Nowadays, English is one of the international communication languages. Indonesia is one of the countries that recognized English as a foreign language. English is mainly used in classrooms in this country, while outside of the classroom, they used their native language for daily interaction. English is regarded as an essential foreign language in Indonesia. It is evident that this language is taught as a compulsory lesson from junior high school until university; even in the big city, English is taught since kindergarten. According to Samad, Jannah, \& Fitriani (2017, p. 29), almost all countries recognized English as a foreign language, including Indonesia. Mahmud (2017, p. 37) supported that the importance of English as an international language is admitted worldwide as a means of science and technology.

There are four primary skills taught in language learning: writing, listening, speaking, and reading skills. According to Kurniasih, Sholihah, Umamah, \& Sung (2020, p. 144), English students must have a good command of English both in written and spoken form. Each language skill has its own difficulties. The four skills in language learning support it. Furthermore, Mahmud (2017, p. 37) states that writing is considered a difficult skill, and therefore, the teaching of writing needs more specific strategies. The notion was in line with Suastra \& Menggo (2020, p. 432) that writing skills requires EFL learners to employ their linguistic competence to generate the main idea, supporting the idea, sum up the concept of the experts, have sufficient knowledge of diction choice, topic selection, punctuation, make good connection among sentences, and find appropriate references.

Based on preliminary observation at Junior High School Lopok, the writer found that most students have difficulties writing a descriptive text. The main problems were the students have difficulties in organizing and developing their description of an object which is being described in the descriptive text. They usually get stuck in writing descriptive text. Furthermore, they are not eager to learn, and they have low motivation to write. According to Adnyani, Sari, Suputra, Pastika, \& Suparwa (2018, p.320), the implemented teaching technique needs to be supported with exciting, enjoyable, easy-to-understand learning materials. Teachers need to employ exciting techniques and methods, including new teaching mediums, to motivate students and promote writing enjoyment. The 
idea was parallel to Umar \& Sudipa, N. (2020, p. 794) stated that foreign language teachers are challenged to provide exposure to language; and provide opportunities for learning through classroom activities. Furthermore, they claimed that in class, teachers play a significant role in bringing students the idea that language learning can be fun. In addition, Ningsih (2020, p. 1415) that engaging media is critical to attracting young learners' attention; in teaching English, the teacher should be supported by songs, videos, realia, games, cartoons, ICT, et cetera.

The most urgent problem to be addressed in this development study is to develop a learning model. Technology has become an essential part of language learning at all different levels globally, while interest in learning languages in general and English has increased tremendously. Nariyati, Sudirman, \& Pratiwi (2020, p. 38) suggest the same; they stated that in the 21st century, the educational process had been changed by the development of technology. It is supported by Shyamlee \& Phil (2012, p. 150) that technology is utilized for the improvement of modern styles; it satisfies both the visual and auditory senses of the students.

An English teacher must use appropriate strategies and develop a learning model in teaching writing a descriptive text regarding the phenomenon above. This study used virtual technology in teaching descriptive text. Creating virtual technology helped the students in writing because it allows them to express their idea in a fun way. Teaching descriptive text using virtual technology is expected to increase EFL students' descriptive writing skills.

Based on the background above, the issues can be formulated as follows: 1) How do the implementation of virtual reality technology in the descriptive text writing English learning? 2) To what extent is the effectiveness of virtual technology in the descriptive writing skill English learning? The study aims to describe; 1) to know the implementation of virtual technology in the descriptive writing skill English learning, 2) to know the effectiveness of virtual technology in the descriptive writing skill English learning.

\section{LITERATURE REVIEW}

\subsection{The Descriptive Writing}

According to Afifuddin (2016, p. 132), a descriptive text provides a good platform for writers to express their feeling on a subject. Descriptive text is one of the genre types implemented in teaching writing. A descriptive text explains the characteristics of a person or an object. The main aim of descriptive text is to inform about the thing to be described. So, it provides generalized information on facts, qualities, and characteristics about the object under consideration to get a systematic, accurate, and almost photographic description. These texts are just straight facts and do not give the reader any ideas about the feelings or opinions of the author. The descriptive text has structure as below; (1) Identification; identifying the phenomenon to be described. (2) Description; describing the phenomenon in parts, qualities, and characteristics

EFL students may find some general difficulties in writing descriptive text. The first problem is in developing the ideas. Students must write many main ideas in one paragraph; the ideas of the paragraphs are ambiguous. The second problem is in organizing the ideas to write a descriptive text. A paragraph needs more than one unified point. The third problem is that the students were having difficulties with grammar. The fourth problem is that the students have limited knowledge of vocabulary. It is common knowledge that English is not the Indonesian native language. It is difficult for the students to remember all the words in English.

\subsection{The Virtual Reality Technology}

According to Fuchs \& Bishop (1992), virtual reality is "real-time interactive graphics with 3D models, combined with a display technology that gives the user immersion in the model world and direct manipulation". Virtual reality technology plays an essential role in realizing Telesensation. One application of modern technology that can assist in the teaching and learning process is virtual reality. This opinion corresponds to Riyadi, Sumarudin, \& Bunga (2017, p. 75), who state that virtual reality can be integrated with the environment and simulated with a computer. A virtual world is created through it that viewers can enter and walk through where they can handle virtual objects. The virtual world allows us a stereoscopic view from front or side, depending on our viewpoint, just as in the real world.

Virtual reality aims to provide human beings with a virtual environment where we can interact with a computer just as we do in the real world, that is, by talking with a virtual human in a spoken language, writing a letter, or drawing a letter picture. We can grasp a virtual object by hand gesture and bring it to another place. In a human-friendly virtual environment, we can interact with a computer without any difficulties or barriers. When a virtual landscape is generated by VR technology, we can go there just as though it were a natural landscape. Providing a 3D image of the landscape and sound and smell helps us enjoy the scenery.

The new era assigns new challenges and duties to the modern teacher. The tradition of English teaching has been drastically changed with the remarkable entry of technology. According to Shyamlee \& Phil (2012, p. 150), technology provides so many options as making teaching exciting and making teaching more productive. 
International Journal of Social Science (IJSS)

Vol.1 No.2 Agustus 2021, pp: 121-128

ISSN: 2798-3463 (Printed) | 2798-4079 (Online)

DOI: https://doi.org/10.53625/ijss.v1i2.145

Technology is one of the most significant drivers of both social and linguistic change. It is supported by Alves, Miranda, \& Morais (2017, p. 518), who stated that there is an increasing interest in the virtual learning environments supported by the internet, namely among education institutions, students, and teachers.

\subsection{The English language Learning}

Fundamentally, there are many concepts related to English learning. However, there are two concepts of English learning; first, English learning as a second language; second, English learning as a foreign language. Successful language learners should be able to use the language in meaningful interaction with others. It can be in four language skills; spoken, listening, reading, and written form. Meaningful interaction with others in the target language in the classroom is much crucial in language learning. Language learning is supposed to conduct activities to get meaningful interaction for the language learners. Language learning is not a result of transmitting facts about language or from the succession of rote memorization drills. According to Dai (2015, p. 130), their English learning activities or tasks are designed and carried out so that they finally come to the stage of critical thinking and creativity in their English learning.

\section{RESEARCH METHOD Research Method}

The method used by the researcher in this study was a quantitative descriptive research approach. Data was collected pre-test and post-test, and effectiveness was measured by comparing the written test results. The experimental class received treatment through Virtual Reality Technology (VRT) media. This study was conducted at the 64 students (class A and class B) of the eighth grade of Junior High School Lopok Sumbawa.

\section{Pre-test}

The researcher gave the pre-test before giving treatment to the students in both classes (A and B). Its purpose was to measure and define the students' prior ability in descriptive text writing. This test used a descriptive text writing test by giving some topics to the students. The students had to explore their ideas in descriptive text written form without cheating on their friends. The processes were:

a. The researcher explained the procedure of the test to the students.

b. The researcher distributed the test to the students.

c. The researcher asked the students to read the instruction carefully before doing the test.

d. The researcher let the students do the test.

e. The researcher asked the students to submit their work.

\section{Post-test}

The post-test was given to students after treatment using the Virtual Reality Technology (VRT) model. The process was similar to the pre-test process.

Aspects of descriptive text writing assessed in this case are the content, organization, vocabulary, language use, and mechanics. Students' scores resulting from this test were explained descriptively to reveal their capabilities in creating their descriptive text.

Table 1 Classification score of students' capabilities in creating their descriptive text writing

\begin{tabular}{|l|l|}
\hline Classification & Scores \\
\hline Excellent & $81-100$ \\
\hline Very Good & $61-80$ \\
\hline Good & $41-60$ \\
\hline Poor & $21-40$ \\
\hline Very Poor & $0-20$ \\
\hline
\end{tabular}

The score range was excellent when all of the five aspects (content, organization, vocabulary, language use, and mechanics) of descriptive text writing were found in the students' work. An excellent score was given to the students who applied the five aspects of descriptive writing text but still minor mistakes. A good score was given to the students who applied the five aspects of descriptive writing text but still have two or three aspects. The poor score category was given to students' work, which is still missing three or five aspects. The last category of very poor was given to the students of missing all the aspects.

This test compares the students' skills in descriptive text writing before and after treatment using Virtual Reality Technology (VRT) to develop ideas in paragraphs. Both groups' pre-test and post-test results were then compared by looking at the average value and standard deviation. After that, the t-test significance was held by comparing the $\mathrm{t}$ test and the t-value as well as the test of significance. This arrangement is to test the hypothesis $\left(\mathrm{H}_{1}\right)$ in which VRT is 
effective in teaching descriptive text writing and H0, in which VRT is ineffective in teaching descriptive text writing). If the t-value is accepted, it can be concluded that VRT is effective in teaching descriptive text writing.

\section{RESULTS AND ANALYSIS}

This part discusses the two main findings from this study based on the two main problems formulated in this study. The first one is about the implementation of VRT in descriptive text writing English learning and the second one is the effectiveness of VRT in teaching writing, particularly in increasing descriptive writing paragraphs. Implementation of VRT in teaching descriptive text writing

Before deciding to use VR, there are several important considerations. As in many technical innovations, the device needs investment on the teacher's and the student's part. For example, how much time is likely needed for learning the technology and assisting students? In addition, do students have access to capable devices?

There are ten steps in implementing the VRT in teaching descriptive text writing in each meeting;

1) The teacher design teaching material,

2) Teaching materials installed in the Virtual Reality app,

3) Asking the students to make small groups,

4) The teacher explains how to use VRT App,

5) The teacher asks the students about their understanding related to his/her explanation,

6) Asking the students to use the Virtual Reality app one by one each group,

7) The teacher asks the students about their understanding related to the teaching material in the Virtual Reality app,

8) Each group practiced writing descriptive text after seeing the VR App,

9) The results of the writing practice are given to the teacher, and

10) The implementation of VRT in teaching descriptive text writing was finish.

The effectiveness of Students' descriptive text writing

This part discusses the second main issue in this research was the effectiveness of VRT in teaching descriptive text writing, particularly in developing paragraphs. The two groups, experimental and control groups, with the different treatments in teaching writing as explained above, were given a test of writing before and after the treatment. The test was asking students to write a paragraph based on specific topics.

Table 2. The descriptive analysis results of the pre-test and post-test of Class A can be seen in the following table:

\begin{tabular}{|l|l|l|l|l|l|l|}
\hline & N & Minimum & Maximum & Sum & Mean & Std. Dev. \\
\hline Pretest & 32 & 64 & 73 & 2199 & 68.72 & 2.275 \\
\hline Posttest & 32 & 79 & 94 & 2675 & 83.59 & 3.425 \\
\hline Valid N & & & & & & \\
\hline
\end{tabular}

As shown in Table 2, on the pre-test, the minimum score was 64 , and the maximum score was 79 , while on the post-test, the minimum score was 73 , and the maximum score was 94 . Furthermore, the mean score on the pretest was 68.72 , while on the post-test, the mean score was 83.59. The increase of mean score after implementation of VRT media was $21.64 \%$. Based on Table 3, we can see that the average rating of a post-test (83.59) was more significant than the average score of a pre-test (68.72).

Table 3. The Result of Paired Samples T-Test of Class A

\begin{tabular}{|c|c|c|c|c|c|c|c|c|}
\hline & \multicolumn{5}{|c|}{ Paired Differences } & \multirow[t]{3}{*}{$\mathrm{t}$} & \multirow[t]{3}{*}{$\overline{\mathrm{df}}$} & \multirow{3}{*}{$\begin{array}{ll}\begin{array}{l}\text { Sig. } \\
\text { tailed })\end{array} & \text { (2- } \\
\end{array}$} \\
\hline & \multirow[t]{2}{*}{ Mean } & \multirow[t]{2}{*}{$\begin{array}{l}\text { Std. } \\
\text { Dev. }\end{array}$} & \multirow[t]{2}{*}{$\begin{array}{l}\text { Std. } \\
\text { Error } \\
\text { mean }\end{array}$} & \multicolumn{2}{|c|}{$\begin{array}{l}95 \% \text { Confidence } \\
\text { Interval of the } \\
\text { Difference }\end{array}$} & & & \\
\hline & & & & Lower & Upper & & & \\
\hline $\begin{array}{l}\text { Pretest- } \\
\text { Posttest }\end{array}$ & -14.875 & 3.982 & .704 & -16.311 & -13.439 & -21.133 & 31 & .000 \\
\hline
\end{tabular}

Based on the data analysis displayed in Table 3, the result showed that the paired sample t-test on class A found sig. (2-tailed) 0.000 , value T-count -21.133 , can be positive, meaning 21.133, and the value of mean paired differences was -14.875. Data obtained that sig. (2-tailed) $0.000<0.05$, and value T-count $21.133>$ T-table 2.039, 
International Journal of Social Science (IJSS)

Vol.1 No.2 Agustus 2021, pp: 121-128

ISSN: 2798-3463 (Printed) | 2798-4079 (Online)

DOI: https://doi.org/10.53625/ijss.v1i2.145

for the significance level $\alpha=0.05 \mathrm{n}=32$. It concluded that the use of VRT media was significant, on students' descriptive writing skills, for the eighth grade of Junior High School in the Sumbawa District.
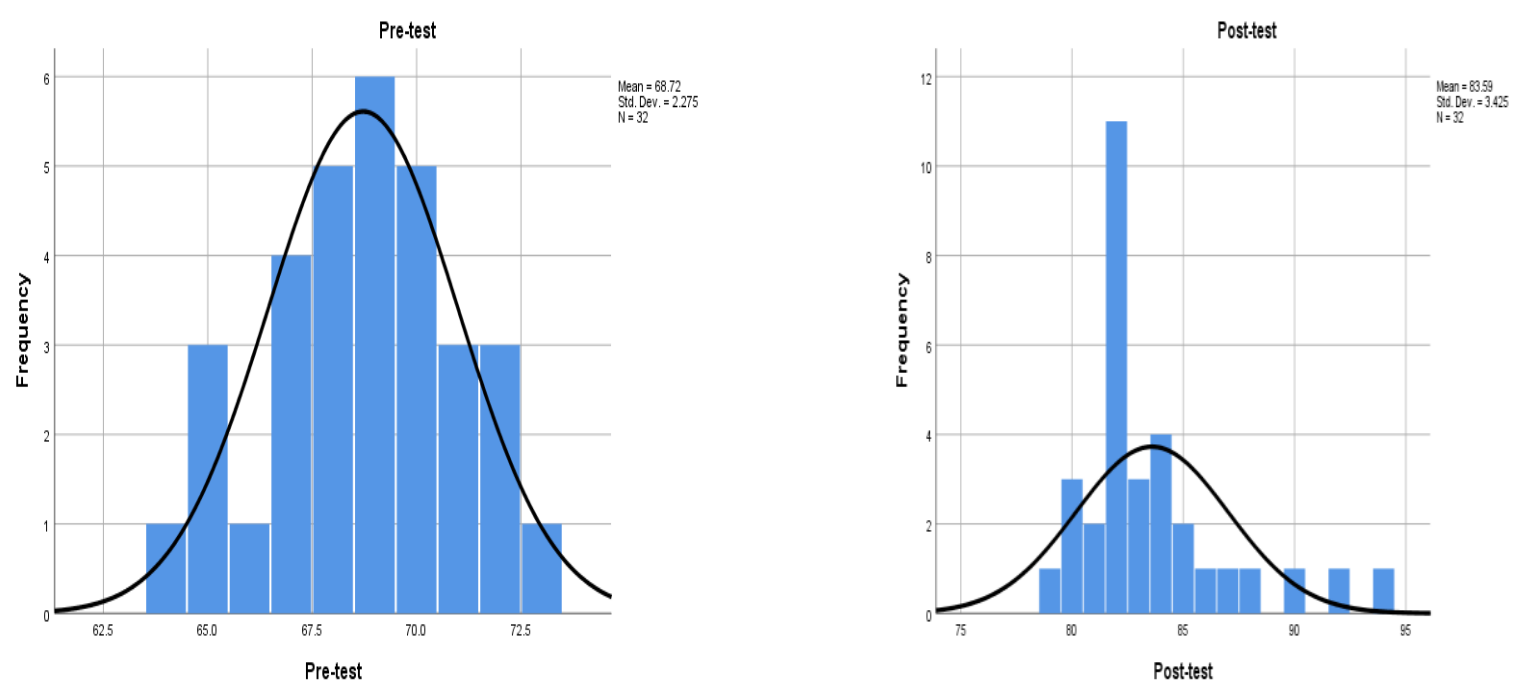

Figure 1. Normality of the Class A Distribution Data

Table 4. The results of descriptive analysis of the pre-test and post-test of Class B can be seen in the following table:

\begin{tabular}{|l|l|l|l|l|l|l|}
\hline & N & Minimum & Maximum & Sum & Mean & Std. Dev. \\
\hline Pretest & 32 & 51 & 71 & 1997 & 62.41 & 5.604 \\
\hline Posttest & 32 & 74 & 84 & 2524 & 78.88 & 2.837 \\
\hline Valid N & & & & & & \\
\hline
\end{tabular}

As shown in Table 4, on the pre-test, the minimum score was 51, and the maximum score was 74 , while on the post-test, the minimum score was 71 , and the maximum score was 84 . Furthermore, the mean score on the pretest was 62.41, while on the post-test, the mean score was 78.88. The increase of mean score after implementation of VRT media was $26.39 \%$. Based on Table 5, we can see that the average rating of a post-test (78.88) was more significant than the average score of a pre-test (62.41).

Table 5. The Result of Paired Samples T-Test of Class B

\begin{tabular}{|c|c|c|c|c|c|c|c|c|}
\hline & \multicolumn{5}{|c|}{ Paired Differences } & \multirow[t]{2}{*}{$\mathrm{t}$} & \multirow[t]{2}{*}{$\mathrm{df}$} & \multirow{3}{*}{$\begin{array}{l}\text { Sig. } \\
(2- \\
\text { tailed) }\end{array}$} \\
\hline & \multirow[t]{2}{*}{ Mean } & \multirow[t]{2}{*}{$\begin{array}{l}\text { Std. } \\
\text { Dev. }\end{array}$} & \multirow[t]{2}{*}{$\begin{array}{l}\text { Std. } \\
\text { Error } \\
\text { mean }\end{array}$} & \multicolumn{2}{|c|}{\begin{tabular}{|lrl}
$95 \%$ & \multicolumn{2}{c}{ Confidence } \\
Interval of the \\
Difference
\end{tabular}} & & & \\
\hline & & & & Lower & Upper & & & \\
\hline $\begin{array}{l}\text { Pretest- } \\
\text { Posttest }\end{array}$ & -16.469 & 5.685 & 1.005 & -18.518 & -14.419 & -16.387 & 31 & .000 \\
\hline
\end{tabular}

Based on the data analysis displayed in Table 5, the result showed that the paired sample t-test on class B found sig. (2-tailed) 0.000 , value T-count -16.387 , can be positive, meaning 16.387 , and the value of mean paired differences was -16.469 . Data obtained that sig. (2-tailed) $0.000<0.05$, and value T-count $16.387>$ T-table 2.039, for the significance level $\alpha=0.05 \mathrm{n}=32$. It concluded that the use of VRT media was significant, on students' descriptive writing skills, for the eighth grade of Junior High School in the Sumbawa District. 

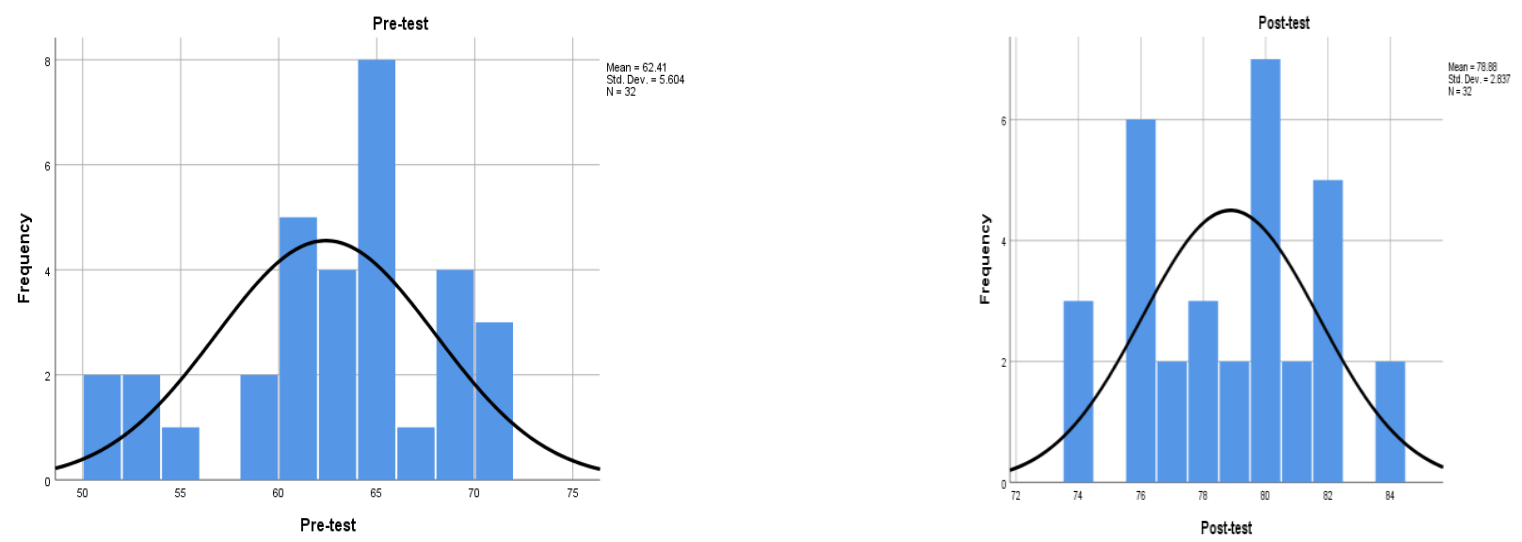

Figure 2. Normality of the Class B Distribution Data

\section{CONCLUSION}

Based on the data analysis above, it can be concluded that (1) the implementation of ten steps of the Virtual Reality Technology in teaching descriptive text writing can increase students' writing skills, especially in developing descriptive paragraphs. The use of VRT as a medium to develop paragraphs contributed a lot to the ways to enhance the creativity of the students to write, and (2) the result of descriptive analysis and inferential statistics with paired sample t-test showed that Virtual Reality Technology significance effect to increase students' descriptive text writing English learning. The result can be seen on both classes (A \& B) as follows; (1) data obtained from class A that the increase of mean score after implementation of VRT media was $21.64 \%$, and the average rating of a post-test (83.59) was greater than the average score of a pre-test (68.72) with excellent level and sig. (2-tailed) $0.000<0.05$, and value T-count $21.133>$ T-table 2.039, for the significance level $\alpha=0.05 \mathrm{n}=32$, and (2) data obtained from class B the increase of mean score after implementation of VRT media was $26.39 \%$, and the average rating of a post-test (78.88) was greater than the average score of a pre-test (62.41) with an excellent level and that sig. (2-tailed) $0.000<0.05$, and value T-count $16.387>$ T-table 2.039, for the significance level $\alpha=0.05 \mathrm{n}=32$.

\section{ACKNOWLEDGEMENTS} article.

Thank you very much for A. Rahman and Anwar, who provide suggestions and feedback to improve this

\section{REFERENCES}

[1] Adnyani, N. L., Sari, R. A., Suputra, P. E., Pastika, I. W., \& Suparwa, I. N, "Implementing ICT-Based Phonology Learning Material Using Blendspace through Classroom Action Research. Aksara, 30(2), pp. 319-330, 2018.

[2] Afifuddin, "An Analysis of Students' Errors in Writing Descriptive Texts," English Education Journal (EEJ), 7(1), pp. 130-139, 2016.

[3] Alves, P., Miranda, L., \& Morais, C, "The Influence of Virtual Learning Environments in Students' Performance," Universal Journal of Educational Research, 5(3), pp. 517-527, 2017.

[4] Dai, Z, "The Concept of "English Learning Power" and its Implication for the Design of English Curricula for Primary and Middle Schools in China," Journal of Education and Practice, 6(36), pp. 128-133, 2015.

[5] Fuchs H., Bishop G, Research Directions in Virtual Environments. Chapel Hill, NC: University of North Carolina at Chapel Hill, 1992. 
International Journal of Social Science (IJSS)

Vol.1 No.2 Agustus 2021, pp: 121-128

ISSN: 2798-3463 (Printed) | 2798-4079 (Online)

DOI: $\underline{\text { https://doi.org/10.53625/ijss.v1i2.145 }}$

[6] Kurniasih, Sholihah, F. A., Umamah, A., \& Sung, I. H, "Writing Process Approach and Its Effect on Students' Writing Anxiety and Performance," Jurnal Arbitrer, 7(2), pp. 144-150, 2020 .

[7] Mahmud, M, "Teaching Students to Develop Paragraphs by Poetry Writing, "International Journal of Language Education, 1(1), pp. 37-50, 2017.

[8] Nariyati, N. P., Sudirman, \& Pratiwi, N. P, "EFL Pre-Service Teachers' Perception Toward the Use Of Mobile Assisted Language Learning in Teaching English," International Journal of Language Education, 4(1), pp. 38-47, 2020.

[9] Ningsih, P. E, "The Use of Freeze Framing Technique for Teaching English to Young Learners at Town for Kids Preschool Jambi," Jurnal Inovasi Penelitian, 1(7), pp. 14131426, 2020.

[10] Riyadi, F. S., A.Sumarudin, \& Bunga, M. S, “Aplikasi 3D Virtual Reality sebagai Media Pengenalan Kampus Politeknik Negeri Indramayu Berbasis Mobile," Jurnal Informatika dan Komputer (JIKO), 2(2), pp. 75-82, 2017.

[11] Samad, I. A., Jannah, M., \& Fitriani, S. S, "Efl Students' Strategies Dealing With Common Difficulties in Toefl Reading Comprehension Section," International Journal of Language Education, 1(1), pp. 29-36, 2017.

[12] Suastra, I. M., \& Menggo, S, "Empowering Students' Writing Skill through Performance Assessment," International Journal of Language Education, 4(3), pp. 432-441, 2020.

[13] Shyamlee, S. D., \& Phil, M, "Use of Technology in English Language Teaching and Learning": An Analysis. IPEDR, 33, pp. 150-156, 2012.

[14] Umar, \& Sudipa, N, "The Effectiveness of Environment-based Reading Material in Increasing Students' Vocabulary in EFL Learning in the Eighth Grade of Sumbawa District Junior High School," Journal of Language Teaching and Research, 11(5), PP. 793-800, 2020 . 
